\title{
Friedrich Engels and the Technoscientific Reproducibility of Life: Synthetic Cells as Case Material for Practicing Dialectics of Science Today
}

\section{HUB ZWART}

\begin{abstract}
Friedrich Engels' dialectical assessment of modern science resulted from his fascination with the natural sciences (cell physiology, thermodynamics, theory of evolution) in combination with his resurging interest in the work of "old Hegel." Engels became especially interested in what he saw as the molecular essence of life, namely proteins or, more specifically, albumin (Eiweiß), seeing life as the mode of existence of these enigmatic substances. Hegelian dialectics is crucial for a dialectical materialist understanding of contemporary technoscience. The dialectical materialist understanding of technoscience as a research practice builds on Engels, but also on later (scientific) authors who were inspired by his writings, e.g., life scientists such as Haldane and Bernal. Considering the criticism raised against Engels' dialectics by 20th-century Marxists, a dialectical diagnostic of contemporary technoscience can be achieved, which shifts the focus from artificial albumin as "living matter" (as discussed by Engels) to contemporary research on synthetic cells (as anticipated by Engels).
\end{abstract}

KEYWORDS: Dialectics of nature; dialectical materialism;

Friedrich Engels; synthetic biology; philosophy of science;

Marxism and science 


\section{Introduction: Dialectics of Science and Nature as a Research Program}

$\mathrm{F}$ IRIEDRICH ENGELS DEVELOPED HIS dialectics of science and nature ${ }^{1}$ in his correspondence with Karl Marx, but more systematically in his Anti-Dühring (1878) and in Dialectics of Nature (1925), a collection of notes and manuscripts which he left unfinished. Dialectics, for Engels, is the science of the laws of motion and development of nature, society and thought $(1962,11,132)$. The Marx-Engels correspondence (1983) served as a laboratory where important scientific developments were quite regularly discussed. These epistolary exchanges addressed a broad range of scientific topics, from Justus von Liebig's and James Johnston's work on organic and agricultural chemistry via Darwin's The Origin of Species up to John Tyndall's experiments on light scattering. Engels began his dialectical analyses of science in the late 1850s, building on the work of Hegel. In a letter to Marx (July 14, 1858), he announces his intention to reread Hegel to find out to what extent the latter anticipated recent progress made in the natural sciences, notably in physiology (e.g., cell biology) and chemistry. In this letter, Engels already outlines how he sees the cell as the Hegelian being-in-itself and the living organism as the realization of the "idea" of life, while comparative physiology demonstrates how quantitative changes give rise to qualitative leaps (Marx and Engels, 1983, II, 326). Unfortunately, Engels' extensive research efforts were significantly hampered by competing time-consuming activities, not only his professional work at the offices of Ermen \& Engels in Manchester, but also the posthumous editing of parts II and III of Marx' Capital (Hunt, 2009). The question addressed in this paper is: to what extent Engels' dialectical views are still relevant for addressing recent developments in contemporary science. My objective is to update dialectical materialism by raising a question comparable to the ones addressed by Engels in the 19th century, namely: how to assess contemporary science from a dialectical perspective? What would a

1 Engels himself did not use the term "dialectical materialism," which was coined by Joseph Dietzgen in Das Wesen der Menschlichen Kopfarbeit [The Nature of Human Brainwork] as a form of dialectics that allegedly superseded Hegel's version, which had become "reactionary" (Dietzgen, 1961) — although Karl Kautsky and Georgi Plekhanov are also often mentioned as early adopters of the term (Sheehan, 1985/2017). 
dialectics of contemporary life sciences research amount to? How to practice dialectics of science and nature today?

Engels' dialectics of science and nature (as a personal research program) resulted in four core texts:

- Dialectics of Nature, a collection of manuscripts written between 1876 and 1878 and published posthumously in 1925 (Engels, 1962)

- The Marxist classic Herrn Eugen Dühring's Umwälzung der Wissenschaft (AntiDühring), dating from the same period, written between 1876 and 1878 and published in 1878, after having been serialized in the German socialist periodical Vorwärts (Engels, 1962)

- Socialism: Utopian and Scientific, first published in 1880 and based on excerpts from Anti-Dühring (Engels, 1962)

- Ludwig Feuerbach and the End of Classical German Philosophy, written in 1886 and published the same year (Engels, 1962)

These documents reflect at least two over-arching trends in Engels' scholarly activities. First of all, his return to and resurging interest in the work of "old Hegel,"” the philosophical hero of his youth, from the late 1850s onwards, a development which concurred with a similar "return to Hegel" by Marx. ${ }^{3}$ Secondly, a growing interest in the quickly progressing natural sciences, ${ }^{4}$ an interest which he, again, shared with Marx during this same period, although whereas the latter predominantly focused on fields such as agricultural chemistry (Justus von Liebig, James Johnston, Henry Carey) and mathematics (as reflected by his extensive notebooks on differential calculus), Engels mainly occupied himself with physics, (organic and inorganic) chemistry and biology. ${ }^{5}$

In the writings listed above, Engels aspired to come to terms with what he considered as the three decisive scientific discoveries of the

2 A phrase used by Marx and Engels in their correspondence; cf. Engels' letter to Marx of December 3, 1851 and Marx's letters to Engels of August 19, 1965 and March 25, 1868 (Marx and Engels, 1983, I, 292; II, 289; IV, 34).

3 See for instance Marx and Engels, 1983, II, 275, 326. Marx used Hegel's dialectical logic as a scaffold for designing the structure of Das Kapital (Marx and Engels, 1983, III, 393-402; Arthur, 2004).

4 In his correspondence with Engels, Marx underscored the socioeconomic importance of the scientific work of, for instance, Humphry Davy and Justus von Liebig (cf. Bernal, 1936).

5 Engels intensely acquainted himself with the natural sciences after stepping down from commerce and moving from Manchester to London, where he went through a process of re-education in mathematics and natural science: a thorough scientific "moulting" ("Mauserung"; 1878/1962, 11; Hunt, 2009, 288). An important influence was the "red" chemist Carl Schorlemmer (1879), a close friend of both Marx and Engels (Benfey and Travis, 1992). 
19th century (Engels, 1886/1962, 294), namely: a) the cell; b) the laws of thermodynamics (conservation of energy and increase of entropy); and c) the theory of evolution. All three discoveries revolve around the question of life. The cell is the basic structural unit of living entities: the prototypical realization of the idea of life as such. As to thermodynamics, one could argue that, while the first law represents conservation as the first dialectical moment $\left(\mathrm{M}_{1}\right)$, which is negated by entropy (conceived as negativity, i.e., as the second dialectical moment, $\mathrm{M}_{2}$ ), then life (more concretely: a microbe or a living cell) represents the negation of the negation: the third dialectical moment $\left(\mathrm{M}_{3}\right)$. Indeed, life is "negative entropy," as Erwin Schrödinger phrased it (Schrödinger, 1944/1967; cf. Zwart, 2013) to capture the astonishing ability of living systems to maintain and reproduce high levels of complexity, and to withstand environmental entropic pressures for extended periods of time. Finally, the theory of evolution represents the historical dimension of life, urging us to see life as something that is perpetually in flux and continuously changing.

In the context of these research activities, Engels devoted special attention to what he saw as the molecular or noumenal essence of life, namely proteins or, more specifically, albumin (Eiweiß). As will be discussed in more detail below, Engels basically saw life as the mode of existence of proteins. Whereas abiotic, inorganic entities are damaged and destroyed by entropic metabolism, in living entities metabolism is incorporated and transformed into sustainable biochemical processes. Engels' thoughts about proteins and cells evidently built on Hegel's philosophy of nature, notably the latter's dialectical analysis of the chemical process (Hegel, 1830/1983, §326; §335) where he argues that the chemical process is an analog of life in the sense that, if the chemical process would continue itself spontaneously, it would be life. Indeed, there is a glimpse of vitality in the chemical process (Hegel, 1830/1970b, §335; Ferrini, 2011, 208), but contrary to inorganic chemical processes, which do not renew or reproduce themselves on their own accord, Hegel argues, life is a self-renewing chemical process made perennial.

Last but not least, Engels already predicted that, one day, scientists will be able to produce proteins artificially (in vitro) in their laboratories. And if they succeed in doing so, he argued, these artificial proteins will undoubtedly exhibit the phenomena of life (e.g., organic metabolism), however weak and short-lived these may be. In 
other words, Engels anticipated (on various occasions) the creation of artificial life in the laboratory as the inevitable "end" (dialectically speaking) of modern biochemical research.

Precisely this latter development is currently evolving from "utopia" to "science," as Engels once phrased it (1880/1962). For indeed, at this very moment, scientific research consortia are trying to build synthetic cells in man-made laboratories. As a (dialectically inspired) philosopher of science, I myself happen to be actively involved (as a principal investigator) in one of these projects, namely the BaSyC project, an acronym which stands for Building a Synthetic Cell (http:/ / www.basyc.nl). As indicated above, the question addressed in this paper is, to what extent Engels' dialectical views are still relevant today, notably for philosophers who aim to come to terms with the conceptual implications and socio-cultural consequences of synthetic cell research, as a high-profile, trans-disciplinary and cutting-edge area of inquiry.

Assessing the relevance of Engels' writings for contemporary philosophy of technoscience proves a complex and challenging issue, however. First of all, we have to determine what a dialectical (or dialectical materialist) assessment of life and the life sciences amounts to, both conceptually and methodologically. Second, Engels' dialectics of nature became a highly controversial endeavor, especially within Marxist discourse itself (Sheehan, 1985/2017; Kangal, 2019), since many Marxists explicitly dismissed it, often favoring a Machist or neoKantian approach to science instead. Therefore, in a paper devoted to this topic, the multiple controversies raised by Engels' writings up to this day cannot be ignored. ${ }^{6}$ Last but not least, Engels developed and published his ideas, notably during the 1870s and 1880s, and the life sciences evidently experienced a series of dramatic revolutionary transitions since then. Therefore, rather than “applying” Engels' view,

6 "Engels was at the root of whatever was wrong with Marxism. With few exceptions, the argument against Engels had now become a virtual orthodoxy, perhaps best summarized in Norman Levine's The Tragic Deception: Marx Contra Engels (1975)" (Rees, 1994). Besides the many Marxist authors who vehemently criticized Engels, there are many others who systematically ignore him. In Slavoj Žižek's Less than Nothing: Hegel and the Shadow of Dialectical Materialism (2012/2013), for instance, Engels is not even mentioned, while in Absolute Recoil: Towards a New Foundation of Dialectical Materialism, his name appears only once, in a quotation borrowed from Lenin (Žižek, 2014, 1), although some phrases may implicitly refer to Engels, such as the remark that the idea of a tension or contradiction between Hegel's dialectical method and Hegel's system — discussed below — is "ridiculous" (2012, 195). Supporters of Engels (Bernal, Haldane, Levins and Lewontin, etc.) often have a scientific background. 
this article will amount to an exercise in extrapolation. Although I will start with the question how Engels himself used dialectics to analyze scientific research concerning the phenomena of life during his own era, the core question for me is the one already brought forward above, namely: how to be a dialectical philosopher of natural science or technoscience today? What would a contemporary dialectics of nature, focusing on synthetic cells (as a symptomatic case study, reflecting broader technoscientific trends) amount to?

The structure of this paper is as follows. I will begin with a short introduction to Hegelian dialectics, focusing on those aspects that are most crucial for developing a dialectical materialist understanding of contemporary technoscience. Subsequently, the outlines of a dialectical materialist understanding of technoscience as a research practice will be fleshed out, building on Engels, but also on later (scientific) authors who were inspired by his writings, e.g., life scientists such as Haldane and Bernal. Next, I will consider the criticism raised against Engels' dialectics by 20th-century Marxists. And finally, I will flesh out a dialectical diagnostic of contemporary technoscience, shifting the focus from artificial albumin as "living matter" (as discussed by Engels) to contemporary research on synthetic cells (as anticipated by Engels).

\section{What Is Dialectics? A Dialectical Materialist Rereading of Hegel}

As Hegel explains in the Introduction (Einführung) to his Phenomenology of the Spirit (Hegel, 1807/1973): Whereas the sciences study natural phenomena (natural processes and entities), thereby developing a (fragmented and partial) phenomenology of nature, philosophy is the science of science: a phenomenology of scientific experiences. Hegel develops a systematic and comprehensive perspective on nature by discerning a dialectical unfolding in the interactions of scientific subjects (researchers) with their scientific objects (natural processes and entities). While science is about knowing or understanding natural objects, philosophy aims to understand the process of knowing as such. It is a critical assessment of the ways in which particular forms of knowledge, emerging at particular moments in history, allow nature to reveal itself. Dialectics is the systematic exposition of scientific research practices, tracing the journey of consciousness passing through various configurations or stations of knowledge towards more comprehensive 
forms of understanding. Thus, dialectics entails knowing about knowing: a phenomenology of scientific experience.

Moreover, science (as a methodological, self-critical endeavor aspiring to come to terms with nature) is inherently dialectical, even if practicing scientists themselves are not always aware of this, because it relentlessly challenges, contradicts and eliminates its own results, in order to reach a more comprehensive level of understanding. In the Introduction to the Phenomenology of the Spirit, Hegel explains how science is never satisfied with its own outcomes. Science, he argues, is a zealous, unhalting process; it finds no satisfaction in existing forms of knowledge, but is driven by an inherent unrest, continuously disturbing and spoiling its own satisfaction: a relentless drive to move further. Existing science is rational, certainly, but this does not mean that scientists are already there, for what is rational about science is first and foremost the scientific method. Science is not a collection of facts and insights, but a process, a practical endeavor, a praxis, whose actual results will only remain temporarily valid. Even the most robust insights will be challenged sooner or later by new findings - spurred on by technological innovations, as Engels will later emphasize. Science progresses through stages and, although all these stages are necessary and inevitable as such, none of them is final. From a dialectical perspective, scientific knowledge production is a process of becoming, continuously unfolding. All existing knowledge forms will evaporate sooner or later, but the rationality and necessity of this (seemingly haphazard) dynamics can be dialectically grasped.

At the same time, dialectics acknowledges a stabilizing tendency in science, namely the tendency to integrate multiple partial knowledge fragments into a coherent theoretical (or even encyclopedic) system. Therefore, two apparently juxtaposed dimensions can be discerned: on the one hand the drive towards theoretical processing and systematic assembling of available research results, and on the other hand the impetus (no less forceful) to challenge, negate, overcome and defreeze these integrative efforts, seeing current knowledge systems as temporary episodes. This tension is also discernible in the edifice of Hegel's own work (Engels, 1886/1962), which on the one hand strives to develop a comprehensive and encyclopedic system of knowledge (the "conservative" dimension) while this system is at the same time challenged and negated by the dialectic method itself (the "progressive" 
dimension). Whereas the scientific revolution continues to unfold, outdated insights become specters and sediments of knowledge, as living science continues to progress farther. Sooner or later, all forms of knowledge will be negated, sublated and transformed. As Engels phrases it, dialectics is not only a phenomenology, but also a "paleontology" of knowledge $(1886 / 1962,269)$, seeing the present as the temporal outcome of a long history, about to give way to newly emerging and proliferating landscapes of research. The Hegelian claim that "all that is real is rational" applies to science insofar as existing theories are exemplifications of the scientific method. Yet, sooner or later, their validity will be undermined; they will be exposed as misguided, or only partially reasonable, and therefore unreal (bound to become mere history). Indeed, all that comes to be, deserves to perish wretchedly (Engels, 1886/1962, 267), as Mephistopheles had already proclaimed, and this also applies to science. For Engels, even Hegel's own impressive encyclopedic system was but a temporary edifice. Sooner or later, it will become a monument to the past, while science as a dialectical praxis continues to unfold, by overcoming the crisis.

Dialectics is a method of thinking which starts from the awareness that thinking itself is subject to a process of becoming. This evidently also applies to dialectics, so that the dialectical method is not a static, but a dynamic procedure that must continuously be refined and transformed. By implication, Engels' version of dialectics, although building on Hegel, at the same time aims to transform and enhance it, to assure that dialectics remains up to its task of effectively addressing the challenges of the dawning era. This requires a thorough understanding of Hegel's thinking, for dialectical materialism is a transformation from within. The force of dialectics consists precisely in this creative tension or interaction between the system-building trend and the dialectical method.

Hegel's prediction about the end of philosophy was correct, Engels argues, in the sense that modern science will indeed abolish philosophy. Philosophy must and will resurge, however, albeit no longer as a separate field (practiced at a safe distance from the turmoil of active scientific research), but as philosophy in science, sublated by and preserved as an inherent self-reflective dimension of the scientific enterprise $(1878 / 1962,129)$. Philosophers should be self-consciously there where science happens. For Engels, philosophy is a dialectical and critical reflection on the dynamics of scientific research as such. 
If we see traditional philosophical contemplation as the first moment of the knowledge production process $\left(\mathrm{M}_{1}\right)$, which was negated, disrupted and marginalized ("dethroned") by modern scientific research $\left(\mathrm{M}_{2}\right)$, the end result will be a negation of the negation: a resurgence of philosophical reflection, but now as an inherent dimension of scientific praxis $\left(\mathrm{M}_{3}\right)$. The science-philosophy divide will become sublated, allowing philosophy to become more relevant and up-todate, while science becomes more comprehensive and advanced (cf. Bernal, 1937). Our current worldview materializes in technoscientific research, while research feeds and transforms our emerging worldview.

This is also the basic message conveyed by Hegel's dialectic of Master and Servant (Zwart, 2017). The Master (initially in control) represents philosophy-as-contemplation, producing abstract universal knowledge, in contrast with the hands-on experiences of the Servant. Eventually, however, the practical knowledge concerning particular aspects of nature produced by Servants (in an interactive, experimental manner, through research-as-praxis) will prove much more powerful and effective than the lofty contemplations of the Master, who, instead of transforming nature, develops a more passive form of contemplation: a worldview. Thus, the initial supremacy of the Master will by subverted by the practical and transformative know-how of the Servant, who actively puts an end to his "bondage" ("Knechtschaft") via epistemic emancipation (Engels, 1925/1962, 480). Empirical science represents the emancipation of the laboring Servant vis-à-vis abstract contemplation (as a privileged but unworldly form of otium). Servants explore and interact with nature more directly, through their experimental work, developing powerful tools to effectively manipulate concrete natural objects, both inside and outside their laboratories. In terms of Hegel's logic, this development reflects the dialectical unfolding from abstract universal knowledge (das Allgemeine, A), via experimental exploration of particular aspects of nature (das Besondere, B), towards the creation and modification of concrete entities (Einzelheit, E), as materializations of the technoscientific approach to life.

\section{What Is Dialectics of Science and Nature (Dialectical Materialism)?}

As indicated, Engels' aim was to update Hegelian dialectics by paying more attention to the practical and material aspects of scientific research. The dialectics of science and nature that results from this 
still builds on Hegelian dialectics, whose great merit had been to see the world (natural, historical as well as intellectual) as a process. Yet, in contrast to Hegel, dialectical materialism stresses the hands-on, interactive dimension of human thinking, the technicity of science, up to the point of acknowledging that science inevitably evolves into technoscience. In Engels' writings on scientific inquiry, there is a consistent emphasis on experimental praxis and on the disclosing and transformative role of scientific and industrial contrivances and instruments.

Dialectical materialism entails the claim that the laws of dialectics not only apply to science, but also to nature as such. The natural sciences are inherently dialectical because dialectics represents the subjective analog of the objective dialectics at work in nature (Engels, 1925/1962, 331; cf. Schweiger 2011, 28). In other words, dialectics applies both to the subject pole (science) and to the object pole (nature) of the knowledge production process. At the subject pole, the emphasis is on scientific research as a form of labor, as a technological praxis as we have seen, highly dependent on advanced means of knowledge production such as microscopes, spectroscopes and telescopes. At the object pole, the emphasis is on movement, as life itself evolves via conflict and contradiction towards higher levels of complexity. Science continuously develops: gradually, but also via dramatic leaps (when quantitative accumulative growth enables qualitative change and disruptive transition). Motion is the mode of existence of matter in general and of living matter in particular, and this applies both to chronic motion (metabolism) and to diachronic motion (evolution).

Engels' most famous work in this area is the Marxist classic, AntiDühring (1878/1962). As Engels himself points out, what began as a polemical essay quickly evolved into an extended "positive" $(6,8)$ exposition of the dialectical method, applying it not only to history and economics, but also to science and nature. The science pole and the nature pole (the subject and the object pole) should not be seen as compartmentalized from each other, but rather as inevitably interpenetrating, for while science allows the natural world to appear in a certain manner, the objects of research challenge researchers to develop their contrivances and approaches in a certain direction. As Hegel already argued, dialectical laws can be discerned both in our scientific experiences concerning nature (the subject pole of knowledge production) and in nature as such (the object pole, where countless 
instances of contradiction and sublation can be pointed out). The chemical process as such, for instance, is inherently dialectical, as Hegel already argued (1830/1983, §326ff.). Basically, Engels aims to demonstrate that scientific research is an inherently dialectical endeavor that will significantly benefit from the conscious and systematic application of dialectical insights and methods. His aim was to save dialectics by rescuing it from the constraints of bourgeois idealism, transporting it to the realm of natural science instead $(1878 / 1962,10)$. Dialectics will allow science to emancipate itself: from the dogmas of traditional metaphysics (which became frozen into scientific concepts), but also from the scientific tendency towards fragmentation and empiricism, at the expense of genuine insight $(1878 / 1926,14)$.

According to Engels, again explicitly building on Hegel, three basic dialectical laws can be distinguished $(1925 / 1962,348)$ : a) the law of the transformation of quantity into quality and vice versa; $b$ ) the law of the interpenetration of opposites; and c) the law of the negation of the negation. Engels' exemplifications of the first law are borrowed directly from Hegel's work. Increasing or decreasing the temperature of water, for instance, is an incremental, quantitative change, until a point is reached at which water suddenly becomes transformed into steam or ice: a qualitative transition (1878/1962, 118). Another example he often uses are carbon compounds, where the addition of elementary components $(\mathrm{C}, \mathrm{H}, \mathrm{O})$ to a particular compound will bring about qualitative change (119). While a certain amount of carbon dioxide is necessary for life, moreover, too much of it transforms it into a poison, and so on.

As to the second law, multiple examples can again be given, such as the opposition between subject and object already discussed above. Natural science represents a relentless productive interaction between science and nature. Technological research practices allow natural objects to emerge in a certain manner, while the object of research (say, a living cell) determines the tools, approaches, mind-set and intentionality of the laboratory subject. Another example is the opposition between heredity and environment (between nature and nurture). Dialectically speaking, it would be one-sided to understand living organisms solely in terms of heredity or genetics (claiming that organisms are their DNA, their genomes), but it would likewise be onesided to see them solely as products of their environment (claiming 
that organisms are the product of environmental factors). ${ }^{7}$ Rather, life results from the constant interaction and interpenetration of both dimensions (heredity and adaptation). Likewise, in chemistry, analysis and synthesis are often regarded as opposites (as processes moving in juxtaposed directions) but in actual laboratory practice, the one is highly dependent on the other, as synthesis (recombination) presupposes analysis (Zerlegung) and vice versa.

The third dialectical principle (the negation of the negation) was also already referred to above. A dialectical process starts from an initial situation or first moment $\left(\mathrm{M}_{1}\right)$, for instance: the rural communism practiced by self-sufficient villages in the pre-industrial past (1880/1962, 2015). As Marx explained in Capital, the rise of capitalism obliterated this rural world, so that farmers were expropriated and forced to migrate into urban areas as battle zones, where a Darwinian struggle for existence raged $(1880 / 1962,216)$ : a process that represented the second moment, the moment of negativity and disruption $\left(\mathrm{M}_{2}\right)$. It involved, among other things, a separation (estrangement) of production and consumption, as food products were no longer produced collectively by consumers themselves (in villages), but in factories, as commodities, so that consumers from now on had to buy these food products (e.g., industrially produced bread, beer, canned meat, etc.) on the market (Zwart, 2000). Traditional agricultural and artisanal knowhow was replaced by scientific knowledge (mathematics, chemistry, logistics, human resource management, etc.) to rationalize and increase the pace and scale of food production. Yet, although industrial production seems rational, it actually results in anarchy and contradictions (highly competitive food markets, environmental pollution, waste, social disruption, etc.). Therefore, a third moment (the negation of the negation) becomes inevitable $\left(\mathrm{M}_{3}\right)$, which will amount to an expropriation of the expropriators (Engels, 1878/1962, 124): the confiscation of the means of production by the working classes and consumers. Scientific knowledge will no longer be the property of the owners (the bourgeoisie), but common knowledge, freely accessible and consciously employed to optimize the agricultural system, also in terms of equity and sustainability.

A similar dialectics is discernible in nature as such, however. According to Engels, the whole of geology is a series of negated

7 The latter position would later (quite un-dialectically) be defended by Trofim Lysenko. 
negations $(1878 / 1962,127)$, as mountain ranges emerge in response to strains in the earth crust, resulting in increased weathering and accumulation of sediments, resulting in new strains, etc. (cf. Bernal, 1936). But we may also use the development of natural organisms as an example: say, a plant. The seed containing the program of life (the "concept" of life; "heredity," $\mathrm{M}_{1}$ ) is exposed to a hazardous, entropic environment (the vegetative version of the trauma of birth) which threatens to negate and eliminate this fragile life form $\left(\mathrm{M}_{2}\right)$, unless the plant manages to use this threatening environment as a resource for growth and protection (the negation of the negation), thus growing into an adult form, as the concrete realization of the $i d e a$, so that two antagonistic forces (nature and nurture, heredity and environment) are reconciled, functioning complementary to each other. Living entities need this dramatic interaction between both components (heredity and environment, nature and nurture) to flourish and thrive. Indeed, they basically are (the product of) this interaction.

\section{From Bourgeois Metaphysics to Dialectics of Science}

Hegel must be credited, Engels argues, for having developed the dialectical method, understanding both the natural and the cultural worlds as processes of becoming $(1878 / 1926,22)$, but he also remained an idealist (23), envisioning history (including the history of science) primarily as a dialectical unfolding of ideas which realize themselves in the course of time, in the form of episodes or stages, challenging, negating and sublating each other. In contrast to Hegel, dialectical materialism emphasizes that thinking (Bewusstsein) is determined by being (Sein) (Engels, 1878/1962, 25). This means that scientific convictions and ideas are shaped in interaction with nature, under specific socioeconomic conditions, in the context of actual research practices in laboratories and industries. Scientific ideas emerge in particular historical settings: they reflect and materialize the technicity of science, i.e., the means of knowledge production developed to enable researchers to effectively address practical challenges. Science is a praxis, and scientific research means practicing science. It is hard work, involving both intellectual and menial components (both brain-work and active manipulation). The industrial revolution owes much to science, but the reverse is also true: science (notably chemistry) owes much to the 
industrial revolution and thrived because of it. Engels points to the connection between thermodynamics and the use of steam engines, for instance, while telescopes were initially developed for military purposes, but he also sees mathematics as grounded in concrete human activities and bodily practices. For him, mathematics is the product of a long history of active engagement with nature (1878/1962, 36). It is only in bourgeois metaphysics that mathematics is conceived as something pure, axiomatic and abstract, so that the idea arises that a line is a point moving through empty space (37), ignoring the grounding of mathematical theory in geodesy and other earthly pursuits. Even mathematical terms like "body" (used for three-dimensional forms, e.g., cube, sphere, etc.) etymologically imply materiality and physicality (38), while the calculus allowed scientists to study processes of continuous change experimentally. It is no coincidence of course that "laboratory" literally means workshop, a locality designed for fabricating knowledge (Zwart, 2019a).

Modern science means: understanding by doing, reflecting a shift (in the history of knowledge) from hands-off (aristocratic) contemplation to hands-on (interactive) experimentation. Bourgeois ideology, however, is hampered by a split consciousness (Zerrissenheit), because it separates practical innovation ("applied research") from "pure" science (the science version of aesthetic disinterestedness, of l'art pour l'art). This split is connected with a whole series of similar compartmentalizations (between science and society, basic and applied research, intellectual and menial activities, etc.). From a dialectical materialist perspective, however, labor (the use and development of technologies and machines) is a necessary precondition for producing scientific knowledge claims, even allegedly "pure" ones. This already applies to Aristotle, Engels argues, a thoroughly dialectical thinker $(1880 / 1962,202)$ who combined philosophical speculation with natural history and anatomy (discovery by doing). Although bourgeois consciousness tends to underestimate the importance of (what is denigratingly referred to as) the Middle Ages, it was during the (late) medieval period that the first industries were created and the first machines were produced, while new instruments became available for experimentation (Engels, 1886/1962, 279; 1925/1962, 457, 462). Moreover, whereas the early modern era (when the bourgeoisie still represented a progressive factor) was a period of revolutionary 
fervor, ${ }^{8}$ during the 17 th and 18th centuries many bourgeois thinkers opted for lofty ("disinterested") contemplation rather than handson experimentation, so that in the 18th century, genuine dialectical works typically emerged outside philosophy proper (in the writings of Diderot and Rousseau for instance; 1880/1962, 202) while it was only in the 19th century that the first truly scientific laboratories were created (by Justus von Liebig and others). Bourgeois thinking tends to see nature as a collection of separate entities (things), rather than as a systemic, dynamic and evolving process (203). The question whether something is alive, for instance, is not a matter of Yes or No, Engels argues, for living and dying are complex, protracted processes, so that metaphysical, scientific or legal attempts to discern a clear caesura between the two are bound to falter (204).

The emphasis on praxis not only applies to the context of discovery, but also to the context of validation and justification, moreover. For Engels, the ultimate proof of the validity of knowledge is provided when we are not only able to understand and predict, but also to actively manage, reproduce and recreate natural processes in our laboratories and industries (Engels, 1925/1962, 497). The artificial, technological reproduction of natural processes in vitro is the ultimate test of the validity of scientific theories. Rather than positing a divide between thinking and being, or between theory and practice, the starting point of dialectical materialism is the unity of theory and praxis brought about by experimentation, putting theories to the test experimentally, and further developing them through experimental trials. Indeed, conducting an experiment means using nature to put our concepts to the test, revealing how nature itself likewise unfolds in accordance with dialectical patterns. Science is not a body of knowledge, but first and foremost a practical endeavor, a systematic interaction with the unfolding environment. The subject and object poles of the knowledge production system interpenetrate each other via the means of knowledge production: scientific instruments handled by scientists that allow the world to appear in a certain

8 Again, Engels discerns a dialectical process here: the medieval period sets in with the fall of Rome and the elevation of Constantinople $\left(\mathrm{M}_{1}\right)$, but is itself eliminated/negated during the fall of Constantinople (the moment of negativity: $\mathrm{M}_{2}$ ) which, paradoxically perhaps, unleashes a return to Greek philosophy and science in Western Europe: the Renaissance as negation of the negation $\left(\mathrm{M}_{3}\right)$. 
manner, as modifiable molecules and organisms for instance, and this allows researchers to produce reproducible knowledge. From a dialectical materialist perspective, there is no divide but rather continuity between laboratories and factories, as well as between universities and industries, and the concept of pure knowledge is a bourgeois fiction. Even logical categories do not exist as pure axiomatic mental entities but rather as ideas that realize and optimize themselves in practice.

Whereas bourgeois metaphysics is imprisoned in mental activities (thinking, consciousness, ego-centric meditations, the mind-body problem), the technicity of science opens up the noumenal dimension of nature: the basic molecular processes of life, energy and matter. And contrary to what bourgeois authors (including Eugen Dühring) claim, thinking is not something we do as individuals. Rather, for Engels, thinking relies on what nowadays would be referred to as distributed intelligence: it is a collective activity involving millions of individuals, dispersed through space and time (Engels, 1878/1962, 80). Constricted ideas produced by single, isolated individuals should be regarded with critical suspicion. At the subject pole, dialectics studies the dialectical unfolding of research programs, which inevitably constitutes a tale of tensions, anomalies and contradictions, where existing knowledge systems (displaying the tendency to freeze into certain modes of thinking), are disrupted and pushed forward by the development of even more powerful and precise machines, whose ground-breaking discoveries may enforce dramatic revisions of dominant ideas (Engels, 1878/1962, 82). And at the object pole, dialectics allows us to see nature not as a series of chance events, but as processes in which dialectical laws are at work and dialectical patterns can be discerned (Engels, 1878/1926, 11).

Contrary to the splendid isolation propagated by bourgeois metaphysics, Engels contends, philosophy should no longer be considered a separate field standing apart from science (1878/1962, 24; 1880/1992, 207). Rather, philosophy should be practiced as an integrated endeavor. "Pure" philosophy has become irrelevant and futile. The end of (bourgeois) philosophy is at the same time a new beginning. Similar to how social philosophy should be practiced in close connection with political activity, the philosophy of science and nature should likewise be practiced in close interaction with actual research endeavors, fostering the further development of the dialectical method. Philosophy of science should become philosophy 
in science, using the dialectical method to bring the dynamics of scientific progress to the fore. And again, modern science is not only a dialectical process itself, but also reveals the dialectical logic inherent in the natural processes it studies.

Dialectically speaking, three moments can be distinguished in the history of thinking. During the initial situation $\left(\mathrm{M}_{1}\right.$, exemplified by Plato and others), philosophy was seen as contemplation, far removed from practical interaction with nature. This is reflected in the Platonic view of nature as perfectly harmonious and balanced, a view which must have been quite at odds with the experiences of artisanal and agricultural laborers of ancient societies, working hard to mold and domesticate nature in a hands-on manner (Zwart, 2009). During the scientific and industrial revolutions of the 19th century, however, philosophy seemed to be negated (dethroned and marginalized) by science and technology $\left(\mathrm{M}_{2}\right)$. As a third moment, dialectics represents a reconciliation in the sense that it reveals how science unfolds by disclosing the dialectical processes at work in nature. The opposition between science and philosophy is sublated as dialectical materialism becomes dedicated to the task of revealing and critically assessing the metaphysics that is unconsciously at work in scientific research. And this reconciliation represents the dialectical "end" of a long history of estrangement (Engels, 1878/1926, 14).

In ancient Greece $\left(\mathrm{M}_{1}\right)$, many Greek thinkers already were materialists and dialecticians $(1878 / 1926,14)$ and even in modern history many examples of "spontaneous" dialecticians can be found ${ }^{9}$ Overall, however, bourgeois metaphysics ${ }^{10}$ (represented for instance by British idealism, e.g., Berkeley, Hume, etc.) tended towards negating materialism and dialectics $\left(\mathrm{M}_{2}\right)$. The existence of an external material world was put into question by idealism and solipsism, ${ }^{11}$

9 Engels mentions Jean-Jacques Rousseau, for instance (1878/1926, 19), who posits an original natural position $\left(\mathrm{M}_{1}\right)$ which is negated by the estrangement of modern society $\left(\mathrm{M}_{2}\right)$, but bound to resurge on a higher level of social complexity in a future society where the opposition between nature and culture is sublated $\left(\mathrm{M}_{3}\right)$.

10 This label refers to a mode of thinking which sees the world in terms of dichotomies and opposites, e.g., subject versus object, society versus nature, is versus ought, etc., and in terms of fixed, separate things (or even things-in-themselves) rather than in terms of processes and relentless change.

11 Christopher Caudwell sees this as the signature characteristic of "bourgeois" epistemology: ceasing to be interested in matter, being exclusively concerned with the mind and subjective reality $(1939 / 2017,30)$. Science, on the other hand, becomes increasingly impersonal. Here, subjectivity becomes eroded and the observer as a concrete subject is eliminated (46). 
while nature was seen as completely deterministic: a world in which nothing (nothing spontaneous or unpredictable) could ever happen. Moreover, bourgeois thinking posited a series of insurmountable divides, between subject (the ego of solipsism) and object (the thing-in-itself), between society and nature, between is and ought, between fact and value, between social science and natural science, etc. This position is now itself being negated, however, by dialectical materialism, which represents a return of materialism, not in the ancient contemplative sense, but informed by two millennia of research $(1878 / 1962,129)$, including the most recent and advanced scientific insights. This dialectical negation of the negation $\left(\mathrm{M}_{3}\right)$ will transcend the dichotomies of bourgeois metaphysics, resulting in a reconciliation, of social science and natural science for instance, so that scientists become conscious of the social dimension of their research as a decidedly social practice. ${ }^{12}$ Dialectics is itself a science: it is philosophy in the form of a science. Its vocation is to consciously develop the dialectical method, but in dialog and interaction with scientific research practices: discerning, articulating and addressing the dialectical processes at work in science.

As to the object pole of the knowledge production process: during the initial situation, in ancient Greece $\left(\mathrm{M}_{1}\right)$, the focus was on nature in general, on being as a whole, on abstract, general, universal ideas about nature (Allgemeinheit, A; Hegel, 1830/1970a, 57). This holistic view was negated by the negativity of modern empirical science $\left(\mathrm{M}_{2}\right)$, which amounted to a breaking down, an analysis (Zerlegung) of natural phenomena into particular components (Besonderheit, B). The negation of the negation $\left(\mathrm{M}_{3}\right)$, entails a return to the whole in the form of a systemic and converging approach, but now on a much higher level of comprehension and understanding, and focusing on concrete entities that exemplify nature or life as such (Einzelheit, E). Thus, initial general insights inevitably give way to divergence and contradiction (Entzweiung), but these are sublated by a third moment, a return (Zurückführung) to concrete convergence (Einigkeit) (Hegel, 1830/1970a, 88).

12 Cf. Bernal (1937): "In contrast with determinism, dialectical materialism explains the emergence of radical new things in nature, such as life and human society, while at the same time showing how science is part of social and historical development, also as a source for generating scientific questions, fostering scientific innovation and discovery." 


\section{Dialectical Materialism Versus Bourgeois Epistemology in Twentieth-Century Marxism}

From the 1920s onwards, Engels' dialectics of science and nature became a controversial endeavor, and his project has remained the target of a substantial stream of polemics ever since, notably in Marxist circles, and notably among authors who aim to restore "pure" Marxism by cleansing it of what they see as contaminations. The dialectics of nature debate was ignited by prominent authors such as György Lukács (Sheehan, 1985/2017; Kangal, 2019) and eventually became a "polemical battlefield" (Kangal, 2019), giving rise to a whole "mountain of literature" (Sheehan, 1985/2017, 54). As Kangal phrases it, no other work has been subject to as much conflict and chaos in Marxist scholarship as Engels' Dialectics of Nature. It is not my purpose to present a full overview of this debate, of course, but I cannot wholly ignore it either. A dialectical materialist perspective on contemporary science must position itself against this turbulent backdrop. Therefore, a concise resume of this debate will be presented, albeit from a dialectical materialist position. As a starting point, I will use the classic Materialism and Empiriocriticism by V. I. Lenin, a staunch supporter of Engels, in 1908 (Lenin, 1908/1979).

In this work Lenin aims to update Engels' dialectics of nature through a polemical review of the theories of Ernst Mach, Richard Avenarius and other "empiriocriticists" (Lenin, 1908/1979). In terms of style and structure, Lenin's book echoes Engels' polemical review of Dühring's work. The empiriocriticists were progressive authors who aimed to develop a new epistemology (a new theory of human understanding) to replace pre-scientific, "metaphysical" conceptions with science-compatible ones, but Lenin's purpose is to demonstrate that they were much less progressive than they thought, because they actually represented a bourgeois epistemology.

Empiriocriticists regard "sense data" (i.e., impressions, observations, sensations, affections, and the like) as the primary starting point of human knowledge and reject the materialistic ("metaphysical") idea that these impressions are produced in us by material things existing in the outside world, independent of human consciousness. There is nothing beyond experience, they argue, no environment without a subject who experiences it. By positing the existence of things beyond sensation, materialism gives rise to an unnecessary 
duplication ("Verdopplung") of the world (13). The material world posited by materialism is discarded as a mystification. According to Lenin, however, by regarding objectivity as a mere product of human subjectivity (by considering the world as a product of human consciousness), these empiriocriticists "plagiarize" (35) the views of the 18th-century bourgeois idealist George Berkeley, who already denied the existence of an outside world, considering it an illusion and claiming that being equals being-perceived (Esse est percipi). Our experiences and sensations are produced in us: not by external things (via our sense organs), Berkeley argued, but by God. In short, according to the empiriocriticists, we only experience experiences (35), while things are merely seen as "complexes of experiences." The world basically is what I experience (61). The existence of non-thinking substance outside human consciousness is systematically eliminated $(17,51)$.

According to Lenin, however, dialectical materialism should hold on to the existence of a material world independent of human consciousness. We experience the existence of external reality primarily by interacting with it, in an active, practical manner, via labor. Human praxis (labor) is our primary source of experience, and this convinces us that the world out there really exists. At the same time, Lenin is clearly aware of the crisis raging in contemporary physics, due to revolutionary discoveries such as X-rays and radioactivity. The material world (e.g., the atom as a basic material entity) seems to evaporate, to dissolve into radiation. Thus, while being aware of the challenge to update dialectical materialism, Lenin nonetheless argues that materialism should remain the starting point.

A dialectical unfolding can be discerned in this debate, in which the first moment $\left(\mathrm{M}_{1}\right)$ is represented by pre-modern metaphysics (say, Aristotle and his medieval followers: Scholasticism), where the soul is considered to be the form of the body. For Aristotle, a concrete living entity is the realization of an idea. This mode of thinking was negated during modernity, however. The modern metaphysical position was inaugurated by Descartes who developed a dualistic view - dividing the world into the ego (human consciousness) as a "thinking thing" (res cogitans) surrounded by extended things (res extensa), thus introducing a compartmentalization between mind and body, as well as between mind and matter (although Spinoza would subsequently argue that the world is one substance, a thinking and extended whole, with two attributes known to us, namely thought and extension, mind 
and body). This second moment $\left(\mathrm{M}_{2}\right)$ was pushed towards its extreme by Berkeley's solipsism, who dropped the existence of external material reality altogether and focused solely on his own mind. As Lenin argues, Empiriocriticism can be considered a fin-de-siècle update of this radical bourgeois stance. By claiming that we only have access to the world of sense data, the existence of a material world independent of and predating human consciousness is negated and discarded as a metaphysical illusion. We are not entitled to posit the existence of things outside (independent of) human experience. $\mathrm{M}_{2}$ entails the negation of the material dimension of the world.

The challenge for dialectics is to reach a higher level of comprehension via a negation of the negation $\left(\mathrm{M}_{3}\right)$, i.e., a position which negates and sublates both pre-modern metaphysics $\left(\mathrm{M}_{1}\right)$ and bourgeois idealism $\left(\mathrm{M}_{2}\right)$, thereby overcoming both antithetical positions. To do this, we must come to terms with the revolutionary and unsettling insights produced by 20th-century science. Rather than relapsing into pre-modern metaphysical conceptions, dialectical materialism aims to develop a science-compatible version of materialism. It is clear that both opposites or antagonists - both traditional (naive) materialism and idealism - have something in common. They both take the phenomenal world of human experience as their starting point, and the issue at stake is whether or not it is admissible to posit the existence of a material world beyond human consciousness. With the help of powerful mathematics and highly advanced technologies, modern science opens up completely unknown and unimaginable dimensions of the material world, far beyond the confines of human understanding: the extremely small world of molecules, atoms and elementary particles (studied by modern chemistry and quantum physics) and the extremely large world of galaxies evolving in spacetime (studied by astrophysics). It is only by coming to terms with science in both directions (the hyper-small and the hyper-large) that dialectical materialism may develop a "sublated" understanding (a negation of the negation).

To phrase this in contemporary terms: the third position neither opts for traditional materialism (since the material world as we know it from everyday experience, and as it is studied by classical physics, is obliterated and eliminated by quantum physics, molecular life sciences research and astrophysics) nor for idealism or Empiriocriticism (the initial "negation" which is now itself negated by this third position). 
Contemporary technoscience discloses an unknown world existing beyond the reach of unaided human consciousness and sensitivity, a world that is unimaginable and imperceptible for us, which defies the basic structures of human experience and is only accessible via advanced mathematics and scientific technicity. Lenin's book, one could argue, represents a moment of transition, hovering somewhere between $\mathrm{M}_{2}$ and $\mathrm{M}_{3}$. He emphasizes (in a polemical manner) the short-comings of Empiriocriticism, is clearly aware of the need for a third dialectical step, but without really being able to realize this step himself because, unlike later authors such as Bernal and Haldane, he studied this debate in libraries and was not really physically there as far as technoscience was concerned.

The second moment represents bourgeois epistemology $\left(\mathrm{M}_{2}\right)$. Its starting point is the ego, which not only gives rise to an egocentric political philosophy (an ideology of individual autonomy and social contracts, of original positions and egocentric self-sufficiency, reflected by the Robinson Crusoe theme, etc.), but also to an egocentric epistemology: the idea that the world is what $I$ experience. While Empiriocriticism is a radical version of this idea, a basic affinity can be discerned with Kantianism and neo-Kantianism as well. Kant had posited the concept of the thing-in-itself (the noumenal dimension of objectivity, beyond the phenomenal realm of human experience), as something which is inaccessible to human understanding. Idealism (Empiriocriticism) merely took the final step: if the noumenal thingin-itself is unreachable, why not get rid of it altogether?

From a dialectical materialism perspective, however, this debate now takes a completely different turn, as we are confronted with the results of contemporary technoscience. After the fin-de-siècle scientific revolution (the discovery of the electron, the emergence of quantum physics, of relativity theory, of genetics, of molecular life sciences research, etc.), the noumenal dimension of nature has been effectively revealed with the help of advanced technicity (e.g., contrivances such as elementary particle colliders, radio telescopes, spectroscopy, etc.). Technoscience as a praxis has effectively disclosed the noumenal realm of natural processes and entities (of protons and quarks, of nucleotides and amino acids, etc.). It has opened up the basic molecular structure of life and matter. Our understanding of materiality has been radically transformed and sublated, so that our conception of materiality as such (from Higgs bosons up to stellar formations) has 
been uplifted, reaching a higher plane of complexity and comprehension $\left(\mathrm{M}_{3}\right)$, and the same applies to our bio-molecular understanding of living systems. In short, although our understanding of matter has dramatically changed since the days of Engels, the existence of an external world as such (the core issue of bourgeois metaphysics) is no longer our major concern. It is marginalized into a purely academic quandary, because the noumenal structure of reality has effectively been made intelligible by technoscience as an interactive research praxis, continuously interacting with matter and nature in an experimental manner (high-tech scientific experimentalism as a particular mode of human praxis). Building on Engels, a dialectical materialist perspective would emphasize the role of scientific experimental labor in this endeavor, which puts an end to futile bourgeois speculations (bourgeois mind games).

Although scholars like Lukács claimed to endorse a dialectical view on human society, they reverted to a bourgeois perspective as far as the realm of science and nature was concerned. These scholars worked in libraries rather than laboratories, quite remote from the actual world of scientific research (Sheehan, 1985/2017). Taking Engels as their key source of inspiration, a genuine dialectical materialist perspective on contemporary science was developed by dialectical scientists such as Haldane and Bernal in the 1930s, in whose writings the tensions between the library and the laboratory perspective on science and nature were sublated and integrated into a comprehensive, genuinely dialectical view.

In Marxist discourse, however, this endeavor (development of a dialectics or dialectical materialist view of nature) remained a contested undertaking. Lukács $(1923 / 1971)$ was probably the first but certainly not the last Marxist to view the application of dialectics to nature as problematic (Kangal, 2019, 218), arguing that dialectics should be limited to the realms of history and society, as the dynamics of contradiction and antagonism should allegedly be seen as a social, not a natural phenomenon.

This is, however, an untenable position, first because dialectics urges us to move beyond such "bourgeois" oppositions (nature versus society, natural science versus social science, etc.). Moreover, the view of nature opened up by the natural sciences in the 20th century reveals a remarkably dialectical series of processes, abounding in antagonisms and contradictions. Novelty emerges in nature 
because of the internal contradictions and crises of previous states (Bernal, 1937). Organic life (as "negative entropy") is inherently dialectical, consisting of constantly emerging and resolving biotic processes (Engels, 1878/1962, 112). Take for instance the theory of evolution (one of Engels' three key discoveries of the 19th century) where the debate over whether nature evolves in a gradual (Darwinian) fashion or in a leap-like fashion (via catastrophes, disruptive transitions, etc.) has been overcome (sublated) by the punctuated equilibrium theory, reconciling both moments on a higher level and arguing that nature (comparable to human society and history) evolves both incrementally and through radical transitions. Or, to stay closer to the work of Engels, consider the development of a natural organism; say, a plant. The seed containing the program of life ("heredity", DNA) is exposed to a hazardous, entropic environment which threatens to negate and obliterate this fragile life form, unless the plant manages to use its environment as a resource for growth and protection (the negation of the negation), so that two antagonistic forces (nature and nurture, genome and environment) eventually complement each other. As was already indicated above, living entities basically are this dialectical interaction. The technicity of modern science takes us far beyond the type of experiences provided by our natural sense organs (as products of evolution). Rather, it opens up the noumenal, molecular "essence" of living systems. But to really and convincingly address this issue, we have to shift our focus towards a concrete dialectical assessment of an actual research practice; which is precisely what the final section of this paper purports to do.

\section{From Artificial Proteins to Synthetic Cells}

Life, according to Engels, is the mode of existence of proteins (Eiweißkörper), ${ }^{13}$ characterized by the constant self-renewal of the chemical constituents of these proteins, a conception that echoes Hegel's view of life as a self-renewing chemical process made perennial, discussed above. Engels uses the term egg-white (Eiweiß) in its modern chemical-industrial sense, as a general denominator for the

13 The term Eiweiß may be translated either in a general sense (as protein), or in a more specific sense, as albumin: the type of proteins egg white contains. 
larger family of protein substances $(1878 / 1962,76) .{ }^{14}$ Wherever we find life, we find proteins, and vice versa. Proteins represent life "an sich"; they are the essence of "naked life" (76). The lowest living beings known to us are aggregates of proteins and they already exhibit all the essential phenomena of life: they absorb and appropriate substances from their environment and assimilate them, while other substances disintegrate and are excreted: a process known as metabolism. Nonliving bodies also change or become involved in chemical combinations (e.g., metals which oxidize and rust), but they thereby cease to be what they were. In living entities, this constant interaction with the environment (a cause of entropic destruction in non-living bodies) is transformed into a fundamental condition of existence (Engels, $1878 / 1962,76)$. As soon as metabolism seizes, they decompose and die. Paradoxically, therefore, life is in a constant state of flux, being every moment both itself and something else, as a result of processes that are self-implemented and inherent to life. Hence it follows that, if chemistry ever succeeds in producing proteins artificially from chemical components (Engels, 1878/1962, 67, 76), these substances must display phenomena of life (metabolism, growth, etc.), however weak these may be, provided scientists find out what the right nutrition for such a substance would be.

Engels perceives life from a dialectical position. Initially, we know life from everyday experience and contemplate it $\left(\mathrm{M}_{1}\right)$, but at a certain point, a more active and experimental approach is adopted, so that living entities are taken apart, dismantled and analyzed. This analysis (Zerlegung) entails an element of violence, resulting in the obliteration of living entities, a process which reveals the negativity of experimental science $\left(\mathrm{M}_{2}\right)$. In order to understand life, scientists systematically destroy (negate) it in their laboratories, in order to find out that living beings, which we know from everyday experience, actually consist of molecular substances called proteins, which can be analyzed further, so that their chemical composition is revealed. The inevitable third step is the negation of the negation $\left(\mathrm{M}_{3}\right)$. Starting from a general

14 Proteins are macromolecules consisting of extended chains of amino acids and performing a vast array of functions within organisms. They were first described by the Dutch chemist Gerardus Johannes Mulder in 1838 (Harold, 1951), who discovered that these substances had the same empirical formula $\left(\mathrm{C}_{400} \mathrm{H}_{620} \mathrm{~N}_{100} \mathrm{O}_{120} \mathrm{P}_{1} \mathrm{~S}_{1}\right)$ (Perrett, 2007). Prior to "protein," which is derived from ancient Greek and means primary (primary substance), other names were used such as "albumins" or "albuminous substances" (Eiweißkörper), derived from "albumin” (egg white). 
understanding of life (A), but proceeding on the basis of accumulated knowledge concerning particular aspects of life (B), scientists will eventually try to reconstruct living matter (proteins) in vitro. The final aim inevitably will be to technologically reproduce proteins: putting the basic components together again to produce something which is a concrete whole - something like an artificial cell (E).

This same line of thinking, developed in Anti-Dühring, can also be encountered in Dialectics of Nature. In 19th-century biology, Engels points out, the discovery of the cell with the help of advanced microscopes revealed that cells indeed constitute the basic realization of the concept of life. Meanwhile, in chemistry, through complementary processes of analysis and synthesis, scientists not only discovered the basic molecular constituents of living (organic) matter, but were also able to produce organic compounds in vitro that hitherto had only been produced in living organisms (in vivo), starting with urea, thereby bridging the gap (the ontological divide) between inorganic and organic nature, which Kant had considered to be insurmountable (Engels, 1925/1962, 318). And while biochemists are working hard to understand life in their laboratories, paleontologists disclose immense paleontological "archives," which one day may help us to understand the origin of life on Earth (322).

As to the subject pole, anthropo-paleontologists reveal the crucial role of tool use and labor in the process of anthropogenesis, the coming into being of human societies and the self-formation of humankind (322), starting with the discovery of the transformation of mechanical motion into heat: i.e., the generation of fire by means of friction (Engels, $1925 / 1962,106)$, and eventually arriving at its counterpart: the transformation of heat into movement via steam engines. Humans are selfmade, Engels argues, and the most important product of human labor is humanity as such, most notably the human hand (1925/1962, 445), which co-evolved with the human brain (232). Technoscientific research itself still exemplifies this formative interaction between the human hand (active experimental manipulation), the human brain (the organ of thinking) and the natural environment, in order to produce viable knowledge concerning the natural world, although modern science has of course moved far beyond Paleolithic conditions by developing a conscious organization of the knowledge production process. Whereas Greek thinkers conceived of nature as a whole, modern research involves an active processing of nature, applying the laws of dialectics, albeit often 
in an "unconscious" manner. But conscious dialectics would optimize this process and result in a more comprehensive view, provided Hegelian dialectics is turned upside down ("umstülpen," 335), transforming it from an idealistic approach (focused on concepts) into a materialist approach (focused on how these concepts materialize in concrete research practices, in concrete interactions with life and matter).

In the 19th century, science resulted in three decisive discoveries, as we have seen: the cell, the laws of thermodynamics and evolution (468). One big challenge is still awaiting us, Engels argues: explaining the origin of life out of inorganic nature. But modern chemistry is bound to reach this goal (469). Since the artificial production of urea by Wöhler in 1828, there are in principle no obstacles to progress further towards the production of more complex substances in the laboratory, including proteins (albumen). Once the molecular composition of proteins is known, moreover, scientists will try their hands at producing living protein, so that the chemical process will give way to the process of life and the gap (allegedly insurmountable) between inorganic and organic nature will be bridged (1925/1962, 318, 319). This will affect the subject pole as well, for as soon as chemistry is able to produce proteins, it will become a qualitatively different type of science, namely the science of artificial life (522).

This again represents an unfolding triadic development, from the discovery of living cells $\left(\mathrm{M}_{1}\right)$, via their chemical analysis $\left(\mathrm{M}_{2}\right)$ towards re-synthesis (convergence, Zurückführung: $\mathrm{M}_{3}$ ). One day, scientists will be able to create life artificially (559), by producing proteins and mimicking metabolic processes. As a result, the basic processes of life will become modifiable in a test-tube. This line of thinking builds on what was already brought forward by "old Hegel" himself, namely that, as soon as the chemical process becomes self-sustainable (becomes metabolism), it becomes life. So-called artificial cells created by Moritz Traube in 1864 did not yet represent genuine metabolism, Engels argues, but it did represent a symptomatic step. Once upon a time, environmental conditions on planet Earth must have been such that the first protein aggregates could arise spontaneously and evolve into primeval primitive organisms. And one day, in modern laboratories, such conditions may again be reproduced in vitro. ${ }^{15}$

15 This idea, the spontaneous origin of life from inorganic matter (generatio aequivoca) is also discussed by Marx and Engels in their correspondence (1983, III, 339; 437). 
Thus, Engels can be credited for having predicted the emergence of efforts to create artificial life in vitro as an inevitable step, eventually resulting in the creation of synthetic cells, as an important dialectical endpoint (turning-point) in the history of science. He thereby prepared the ground for a dialectical assessment of contemporary technoscience, exemplified by projects committed to building a synthetic cell and similar endeavors. A number of authors, notably scientists, have already contributed to the extrapolation of dialectical materialism to contemporary science, such as for instance J. B. S. Haldane (1938/2016) who, building on Engels, defined a number of methodological principles for a dialectical understanding of scientific research, such as the primacy of practice over theory (seeing research first and foremost as a praxis, a systematic experimental interaction with nature, building on the conviction that knowledge claims should be tested and validated in practice). Another principle is that nature should not be considered as a collection of things, but rather as a series of processes. Science is about change and relies on technological contrivances to study these transformative processes with due exactness and precision. Moreover, science itself progresses in a dialectical manner as well, via the negation and obliteration of existing viewpoints. Currently (in the 1930s), Haldane argued, science is bridging the gap between inorganic and organic nature, between chemistry and biology, for instance via the study of viruses: entities that consist of pure nucleic acid (the essence of life as such) contained in a protein capsule. The metabolic processes of life consist of anabolism and catabolism, of building up and breaking down, as opposites which actually must be seen as complementary and as part of the living cell as a concrete, comprehensive whole. And now that the basic constituents of living systems are being explored, the question arises: how to put Humpty Dumpty together again (98)? Increasingly, partial components of living systems will prove replaceable, even in the case of humans, whose organs may one day be replaced by artificial substitutes (a practice currently known as tissue engineering). Genes are beautiful exemplifications of the dialectics (the creative antagonisms) in nature, Haldane argues, containing a program which is constantly trying to adapt to the environment and vice versa (constantly trying to adapt the environment, so that the program may optimally function).

This reflects a dialectical dynamic. Initially, living entities are seen as stable, balanced wholes $\left(\mathrm{M}_{1}\right)$ and the phenomena of life are 
addressed on a general or universal level. Aristotle, for instance, is interested in life as such, in the conceptual understanding of life: das Allgemeine, A). Modern scientific analysis, however, focuses on particular processes and dimensions, such as, for instance, heredity or the environment (das Besondere, B). Here, multiple antagonistic factors and forces are actually at work: productive tensions between heredity and environment, anabolism and catabolism, growth and equilibrium, etc. $\left(\mathrm{M}_{2}\right)$. Finally, we will come to understand how these antagonisms converge into concrete living entities such as living cells, functioning and maintaining high levels of complexity as concrete unities $\left(\mathrm{M}_{3}\right)$. Thus, the living cell is the concrete realization of the idea of life (Einzelheit,E). And to really understand the living cell, one final step has to be made, namely the technical reproduction of a minimal or artificial cell in vitro.

This same idea is further developed by Engels in his treatise Ludwig Feuerbach and the End of Classical German Philosophy (1886/1962). Again, he argues that bourgeois metaphysical convictions, such as the idea of an insurmountable gap between subject and object, between phenomenal experiences and things-in-themselves, between living and non-living entities, between organic and inorganic nature, etc. must be overcome by experimental labor in laboratories and industries: by science as a praxis. Indeed, the ultimate validation of the dialectical materialist conception of natural processes can be achieved by actively reproducing biotic organic entities ourselves, in laboratories and factories. That would finally put an end to the Kantian "thing in itself." Biochemical substances remain "things in themselves" only until biochemistry can artificially produce them, one after the other, because then these processes and substances become things for us. ${ }^{16}$

Dialectics also helps us to come to terms with the enigma of the origin of life. Under current terrestrial circumstances, life can no longer emerge spontaneously (generatio aequivoca seems no longer possible) because life emerged as a third moment in a dialectical unfolding. Initially, primeval organisms (aggregates of living albumin, as Engels phrased it: $\mathrm{M}_{1}$ ) emerged, able to withstand their entropic, abiotic, anaerobic environment $\left(\mathrm{M}_{2}\right)$ which threatened them with destruction. These budding life forms became increasingly able not

16 Cf. Bernal (1937): "Scientists of today are learning to manipulate life very much as their predecessors learned to manipulate chemical substances, so that life ceases to be a mystery and is becoming a utility." 
only to survive, but also to thrive and to use their primeval environment (now known as the primal soup) as a resource for development and growth $\left(\mathrm{M}_{3}\right)$. In the present situation, biotic, aerobic environments effectively block such a trajectory. Indeed, as Levins and Lewontin phrased it, the primary requirement for the origin of life is now the absence of life $(1985,46)$. Under current circumstances, fragile neo-life requires a gnotobiotic, fully controlled environment, which can only be provided by the purified ambiances of technoscientific laboratories (Zwart, 2019b). Thus, the synthetic cell emerges as the concrete realization of the technoscientific concept of life, and as the reconciliation of self-conscious reason (i.e., science) with the reason inherent in existing nature.

But precisely this may also prove a weakness. Should the experiment succeed, the initial experience of success will probably be shortlived: a fate which befalls most if not all the triumphs of scientific inquiry. Before long, discontent will set in, in the form of the experience that, apparently, we have missed something and that these artificial ("fake") cells fail to fully grasp and reproduce the astounding complexities of living systems, so that the synthetic cell will only prove a temporary station on the long and winding pathway of the dialectical unfolding of scientific consciousness. This particular triumph will be negated, but rather than clinging to this particular trial (and the apparently constricted - understanding of life on which it built), technoscience will doubtlessly desire to progress farther. As a positive result, the inevitable experience of Enttäuschung will inform and enable the development of even more advanced programs and efforts to realize a negation of this negation in the future.

Erasmus School of Philosophy (ESPhil)

Erasmus University Rotterdam (EUR)

Bayle Building, Room J5-65

Burgemeester Oudlaan 50, 3062 PA

Rotterdam, The Netherlands

zwart@esphil.eur.nl

REFERENCES

Arthur, Christopher. 2004. “Marx’s Capital and Hegel's Logic.” Pp. 79-111 in The New Dialectic and Marx's Capital. Leiden, The Netherlands: Brill.

Benfey, Theodor, and Anthony Travis. 1992. "Carl Schorlemmer: The Red Chemist." Chemistry and Industry, 56:12, 441-44. 
Bernal, John Desmond. 1936. Engels and Science. Labour Monthly Pamphlets 6. London: Trinity Trust.

—. 1937. "Dialectical Materialism and Modern Science." Science E Society, 2:1, $58-66$.

Caudwell, Christopher. 2017 (1939). The Crisis in Physics. London/New York: Verso.

Dietzgen, Joseph. 1961 (1869). “Das Wesen der Menschlichen Kopfarbeit.” Pp. 15-139 in Ausgewählte Werke I. Berlin: Akademie Verlag.

Engels, Friedrich. 1962 (1878). Herrn Eugen Dührings Umwälzung der Wissenschaft (AntiDühring). Pp. 1-303 in Marx-Engels Werke XX. Berlin: Dietz Verlag.

—_ 1962 (1880). Die Entwicklung des Sozialismus von der Utopie zur Wissenschaft. Pp.177-228 in Marx-Engels Werke XIX. Berlin: Dietz Verlag.

- 1962 (1886). Ludwig Feuerbach und der Ausgang der klassischen deutschen Philosophie. Marx-Engels Werke XXI. Berlin: Dietz Verlag.

— 1962 (1925). Dialektik der Natur. Pp. 305-570 in Marx-Engels Werke XX. Berlin: Dietz Verlag.

Ferrini, Cinzia. 2011. “The Transition to Organics: Hegel's Idea of Life.” Pp. 203-224 in Stephen Houlgate and Michael Baur, eds., A Companion to Hegel. Oxford, UK: Blackwell.

Harold, H. 1951. "Origin of the Word 'Protein'." Nature, 168 (4267), 244. doi: $10.1038 / 168244 \mathrm{a} 0$

Hegel, Georg Wilhelm Friedrich. 1973 (1807). Phänomenologie des Geistes. Werke, III. Frankfurt am Main, Germany: Suhrkamp.

—. 1983 (1830). Enzyklopädie der philosophischen Wissenschaften II. Werke, IX. Frankfurt am Main, Germany: Suhrkamp.

— 1986 (1932). Wissenschaft der Logik II. Werke, VI. Frankfurt am Main, Germany: Suhrkamp.

Hunt, Tristram. 2009. The Frock-Coated Communist: The Life and Times of the Original Champagne Socialist. London: Penguin.

Kangal, Kaan. 2019. "Engels' Intentions in Dialectics of Nature.” Science E् Society, 83:2, 215-243.

Lenin, Vladimir Ilyich. 1979 (1908). Materialismus und Empiriokritizismus: kritische Bemerkungen über eine reaktionäre Philosophie. Werke, 14. Berlin: Dietz Verlag.

Levine, Norman. 1957. The Tragic Deception: Marx Contra Engels. Oxford, UK: Clio Press.

Levins, Richard, and Richard Lewontin. 1985. The Dialectical Biologist. Cambridge, Massachusetts: Harvard University Press.

Lukács, Georgy. 1971 (1923). History and Class Consciousness: Studies in Marxist Dialectics. Cambridge, Massachusetts: MIT Press.

Marx, Karl, and Friedrich Engels. 1983. Der Briefwechsel. München: Deutscher Taschenbuch Verlag.

Perrett, David. 2007. "From 'Protein' to the Beginnings of Clinical Proteomics." Proteomics: Clinical Applications, 1:8, 720-38. doi:10.1002/prca.200700525

Rees, John. 1994. “Engels’ Marxism.” International Socialism, 2:65.

Schorlemmer, Carl. 1879. The Rise and Development of Organic Chemistry. Manchester, UK: Cornish/London: Simpkin \& Marshall.

Schrödinger, Erwin. 1967 (1944). What Is Life? The Physical Aspect of the Living Cell. London: Cambridge University Press. 
Schweiger, Gottfried. 2011. "Naturphilosophie bei Friedrich Engels: Eine Interpretation der Dialektik der Natur.” Pp. 127-146 in E. Hamberger, O. Neumaier, B. Ritterbusch-Nauwerck, and Ed Roscher, eds., Natürlich Kunst. . . Wien/Berlin/ Münster: LIT-Verlag.

Sheehan, Helena. 2017 (1985). Marxism and the Philosophy of Science: A Critical History (The First Hundred Years). London/New York: Verso.

Žižek, Slavoj. 2012. Less than Nothing: Hegel and the Shadow of Dialectical Materialism. London/New York: Verso.

—. 2014. Absolute Recoil: Towards a New Fundation of Dialectical Materialism. London/New York: Verso.

Zwart, Hub. 2000. "A Short History of Food Ethics." Journal of Agricultural and Environmental Ethics, 12, 113-126.

. 2009. "Biotechnology and Naturalness in the Genomics Era: Plotting a Timetable for the Biotechnology Debate." Journal of Agricultural and Environmental Ethics, 22, 505-529.

- 2013. "The Genome as the Biological Unconscious — and the Unconscious as the Psychic 'Genome': A Psychoanalytical Rereading of Molecular Genetics.” Cosmos and History: Journal of Natural and Social Philosophy, 9:2, 198-222.

— 2017. "The Oblique Perspective: Philosophical Diagnostics of Contemporary Life Sciences Research.” Life Sciences, Society E Policy, 13:4. doi:10.1186/s40504017-0047-9

. 2019a. "From Primal Scenes to Synthetic Cells." eLife, 8:e46518. doi: 10.7554/ eLife. 46518

2019b. "Fabricated Truths and the Pathos of Proximity: What Would Be a Nietzschean Philosophy of Contemporary Technoscience?" Foundations of Science. doi: 10.1007/s10699-019-09599-3 